\title{
Atypical Case of Rosai-Dorfman Disease of the Lacrimal Gland with Adjacent Bone Erosion
}

\author{
Mohammad Dahrouj $^{a}$ Frederick A. Jakobiec ${ }^{a, c} \quad$ Natalie Wolkow ${ }^{a, c}$ \\ Victoria S. Starks ${ }^{a, b}$ Nahyoung Grace Lee ${ }^{a, b}$ \\ ${ }^{a}$ Department of Ophthalmology, Harvard Medical School, Boston, MA, USA; ${ }^{b}$ Ophthalmic Plastic Surgery Service, \\ Massachusetts Eye and Ear Infirmary, Harvard Medical School, Boston, MA, USA; ' David G. Cogan Laboratory of \\ Ophthalmic Pathology, Massachusetts Eye and Ear Infirmary, Harvard Medical School, Boston, MA, USA
}

\section{Established Facts}

- Rosai-Dorfman disease is a rare, self-limited, nonmalignant disease characterized by histiocytic infiltration of lymph nodes or extranodal tissue.

- Orbital involvement is extremely rare.

\section{Novel Insights}

- We describe an atypical case of Rosai-Dorfman disease of the lacrimal gland with adjacent bone erosion and optic neuropathy mimicking malignancy.

\section{Keywords}

Rosai-Dorfman disease · Lacrimal gland · Bone lytic lesion ·

Secondary optic neuropathy

\section{Abstract \\ Background/Aims: Rosai-Dorfman disease (RDD) is a rare, self-limited disorder of unknown etiology that affects chil- dren and young adults worldwide and typically manifests as chronic, painless cervical lymphadenopathy. Orbital involve- ment is very rare and may be an isolated extranodal manifes-}

tation or associated with concurrent systemic disease. Adjacent bone involvement is most exceptional, and secondary optic neuropathy has never been reported. Methods: This is a case report with review of the literature. Results: We present a 32-year-old man who, over a 3-month period, developed worsening vision, headache, and vertical diplopia. On examination, there was decreased vision with dyschromatopsia, proptosis, and hypotropia of the left eye. CT scan of the orbits revealed a soft tissue mass inseparable from the lacrimal gland with adjacent bone erosion. Histopathologic evaluation revealed a diffuse infiltrate of histiocytes, lym-

\section{KARGER}

(c) 2018 S. Karger AG, Basel

E-Mail karger@karger.com

www.karger.com/oop
Nahyoung Grace Lee, MD

Massachusetts Eye and Ear Infirmary

243 Charles Street

Boston, MA 02114 (USA)

E-Mail Grace_Lee@meei.harvard.edu 
phocytes, plasma cells, and neutrophils with peripolesis and emperipolesis (tunneling of lymphocytes and plasma cells in the histiocytes' cytoplasm without destruction), consistent with RDD. Resolution of symptoms as well as of the optic neuropathy was achieved with oral corticosteroids. Conclusion: $\mathrm{RDD}$ is an important diagnosis that must be considered in the differential diagnosis of an orbital mass.

(c) 2018 S. Karger AG, Basel

\section{Introduction}

Rosai-Dorfman disease (RDD), also known as sinus histiocytosis with massive lymphadenopathy, was first characterized as a definite clinicopathologic entity in 1969 [1]. RDD is a self-limited, rare disorder of unknown etiology that affects children and young adults worldwide. Typically, it manifests with chronic, painless cervical lymphadenopathy, fever, leukocytosis, and elevated inflammatory markers [1-5]. The disease has a predilection for the lymph nodes in the head and neck. However, extranodal involvement is common and occurs in 28$43 \%$ of cases with manifestations in the upper respiratory tract, salivary glands, skin, bone, and central nervous system $[1,3,4,6]$. Involvement of orbital soft tissue, eyelid, lacrimal gland, conjunctiva, cornea, and retina has been reported. Isolated extranodal manifestations are extremely rare $[2,7-10]$.

\section{Case Report}

A Latino man in his thirties presented to the emergency department with left eye redness and blurry vision. He had intermittent headache with vertical diplopia mainly on left gaze that had progressed over 3 months. One month prior to this presentation, he was diagnosed with viral conjunctivitis. His past medical history was noncontributory, and a review of systems was negative.

On examination, the patient's visual acuity was $20 / 20$ on the right and 20/40 on the left. There was no relative afferent pupillary defect in the left eye, but he did have dyschromatopsia, mild upper eyelid edema, temporal injection, $3 \mathrm{~mm}$ of proptosis, and hypotropia of the left eye (Fig. 1a, b). Furthermore, the patient had limited supraduction and abduction of the left eye. Confrontational visual fields were full, and his anterior segment slit-lamp examination was unremarkable except for conjunctival injection surrounding the palpebral lobe of the left lacrimal gland. Dilated fundoscopic examination was notable for optic disc edema in the left eye with mild hyperemia and chorioretinal folds (Fig. 1c). The exam of the right eye was normal.

Computed tomography (CT) scanning of the orbits revealed a bulky soft tissue mass involving the superolateral left orbit, displacing the globe inferiorly and medially (Fig. 1d, e). The mass was inseparable from the lacrimal gland and was associated with an adjacent focal lytic bony defect in the superolateral orbital wall (Fig. 1f, g). An anterior orbitotomy with biopsy of the left lacrimal gland was performed. An eyelid crease incision was made and dissection was performed toward the superior orbital rim. A subperiosteal dissection plane was taken along the roof of the orbit to allow good exposure. The periorbita was entered over the lacrimal gland mass, and representative tissue was excised for pathology. Intraoperatively, the mass extended posterior to the lacrimal gland and was noted to be firm and rubbery in texture.

Histopathologic examination showed loss of normal lacrimal gland architecture, with periductular sclerosis and a prominent mixed inflammatory infiltrate, which was composed of histiocytes, small lymphocytes, scattered plasma cells, and neutrophils (Fig. 2a, b). Immunohistochemical studies disclosed a mixture of CD3positive T lymphocytes (Fig. 2c), CD20-positive B lymphocytes (Fig. 2d), polytypic CD138-positive plasma cells (Fig. 2e), and numerous CD68- and CD163-positive histiocytes (Fig. 2f). S100 immunostaining demonstrated scattered large histiocytes with conspicuous emperipolesis (Fig. 2g, arrows and inset). CD1a immunostaining was negative, revealing only rare dendritic cells. The histologic and immunophenotypic findings supported the diagnosis of sinus histiocytosis with massive lymphadenopathy (RDD).

The patient responded well to oral corticosteroid therapy $(60$ $\mathrm{mg}$ of prednisone) with improvement in his proptosis and hypoglobus and with complete resolution of optic neuropathy, diplopia, and headaches. He was then referred to the hematology department for further evaluation which did not reveal any systemic involvement. The patient received a repeat CT scan of the orbits 16 months following the surgery. The repeat CT scan (Fig. 1h) showed a decrease in the size of the mass, with sclerosis and remineralization of the adjacent bony defect (Fig. 1i, j).

\section{Discussion}

$\mathrm{RDD}$ is a rare, self-limited, nonmalignant disease characterized by histiocytic infiltration of lymph nodes or extranodal tissue. The etiology of RDD remains unknown and is thought to be due to an idiopathic, uncontrolled histiocytic proliferation. Some reports have suggested a possible role for human herpes virus [5], parvovirus B19 [11], and Epstein-Barr virus [12] in the pathogenesis of the disease. However, no definite etiology has been established, and additional studies are needed. In the familial form of RDD, a germline mutation in SLC29A3, a gene that encodes intracellular equilibrative nucleoside transporter (hENT3), has been reported [13]. This suggests that the familial form of RDD may belong to a spectrum of disorders with SSLC29A3 mutations, including Faisalabad histiocytosis, $\mathrm{H}$ syndrome, and pigmented hypertrichosis with insulin-dependent diabetes mellitus [13].

Gross pathology reveals specimens with a firm, rubbery consistency that are well-circumscribed with capsular or pericapsular fibrosis [14]. On microscopic examination, the hallmark findings of the disease are peripole- 

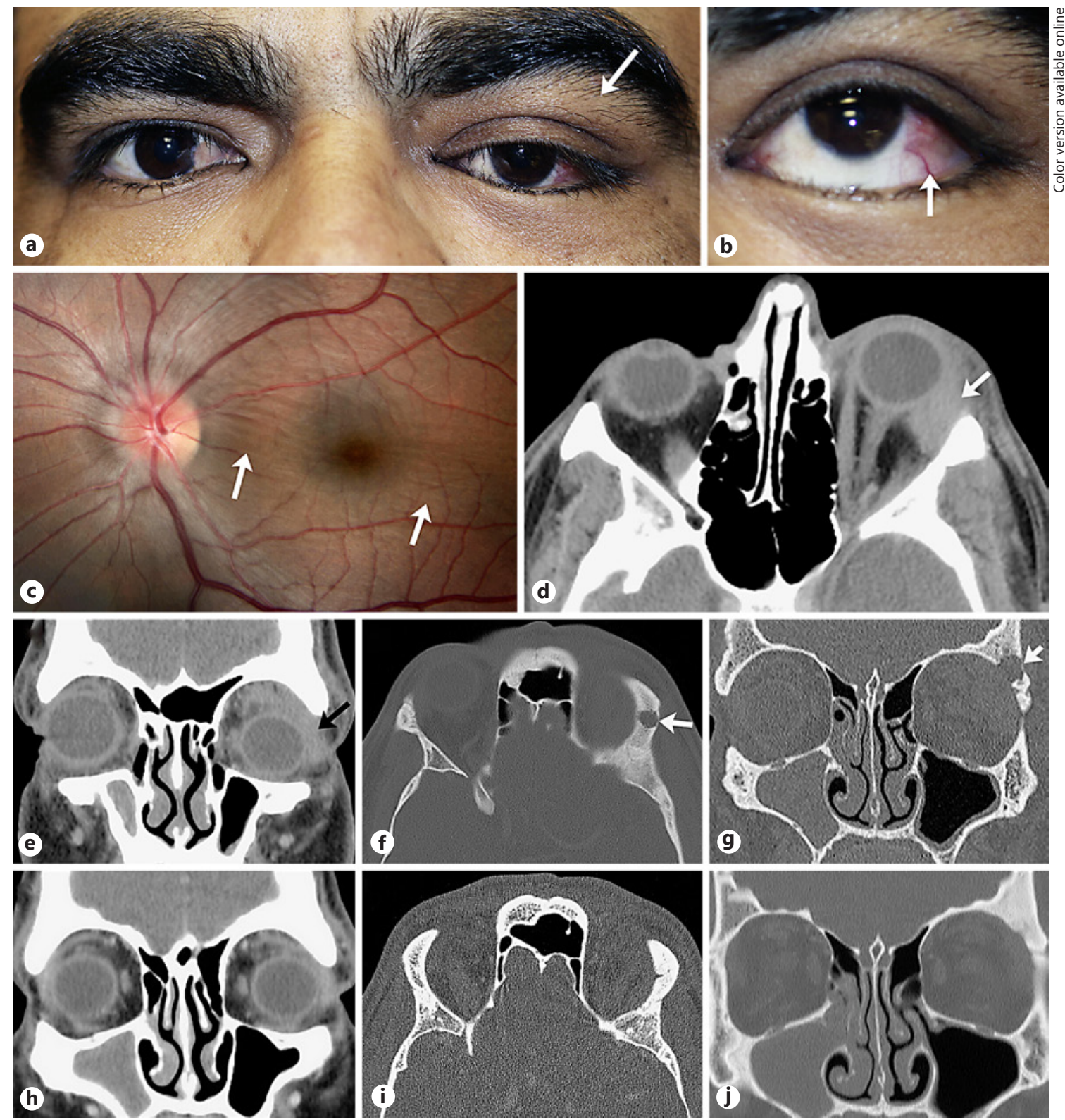

Fig. 1. Clinical findings in a 32-year-old man with Rosai-Dorfman disease of the orbit. a The patient presented with mild left upper eyelid edema, fullness of the left superotemporal orbital tissues (arrow), as well as mild proptosis and inferior displacement of the left globe. b The temporal aspect of the left globe was chronically injected (arrow). c Funduscopic examination revealed an erythematous, mildly swollen optic disc and chorioretinal folds (arrows). d Computed axial tomography demonstrated mild proptosis of the left globe and a hazy superotemporal mass (arrow) that was in- separable from the lacrimal gland tissue. e Computed tomography of coronal image of the superotemporal orbital mass (arrow) causing downward displacement of the left globe. f, $\mathbf{g}$ A lytic bony defect (arrows) was seen in the bone window images of computed tomography adjacent to the mass. $\mathbf{h}$ Computed tomography of coronal image with soft tissue window 16 months following diagnosis. i, $\mathbf{j}$ Computed tomography images with bone window images showing sclerosis and remineralization of lytic bony defect 16 months following diagnosis. sis (lymphocytes surrounding the plasmalemma) and emperipolesis (the nondestructive phagocytosis of lymphocytes or erythrocytes by histiocytes $[1,6]$ ) (Fig. 2g). In early nodal disease, the normal lymph node architec- ture is preserved; however, sinusoidal dilation occurs secondary to infiltration by histiocytes, lymphocytes, or plasma cells $[1,3,6]$. Eosinophils are rarely seen in this condition, in contrast to Langerhans cell histiocytosis 
Fig. 2. Histopathologic features of the biopsied superotemporal orbital mass. a Loss of normal lacrimal gland architecture with only lacrimal gland survival surrounded by fibrosis and a dense inflammatory infiltrate. b The inflammatory infiltrate was composed of a mixture of histiocytes (crossed arrow), plasma cells (arrow), small lymphocytes, and scattered neutrophils. c $\mathrm{T}$ lymphocytes, which immunostained positively for $\mathrm{CD} 3$, were present in the infiltrate. d B lymphocytes, which immunostained positively for CD20, were present in equal numbers to the $\mathrm{T}$ lymphocytes. e Plasma cells were scattered throughout the inflammatory infiltrate, identified here with immunostaining for CD138. f The biopsied tissue harbored numerous histiocytes, as seen with positive immunostaining for CD163. $\mathbf{g}$ The diagnosis of RosaiDorfman disease was confirmed by the presence of S100-positve histiocytes. The arrows indicated characteristic emperipolesis (intracytoplasmic viable lymphocytes in the histiocytes) or peripolesis (lymphocytes rosetting around the histiocytic surface membrane). The inset demonstrates a histiocytic cell, its cytoplasm staining in brown for S100, which has engulfed 2 lymphocytes with clear haloes (emperipolesis). a, b HE, $\times 20, \times 60$. c-g Immunoperoxidase, diaminobenzidine chromagen, hematoxylin counterstain, $\times 20$, $\times 20, \times 40, \times 40, \times 60$.
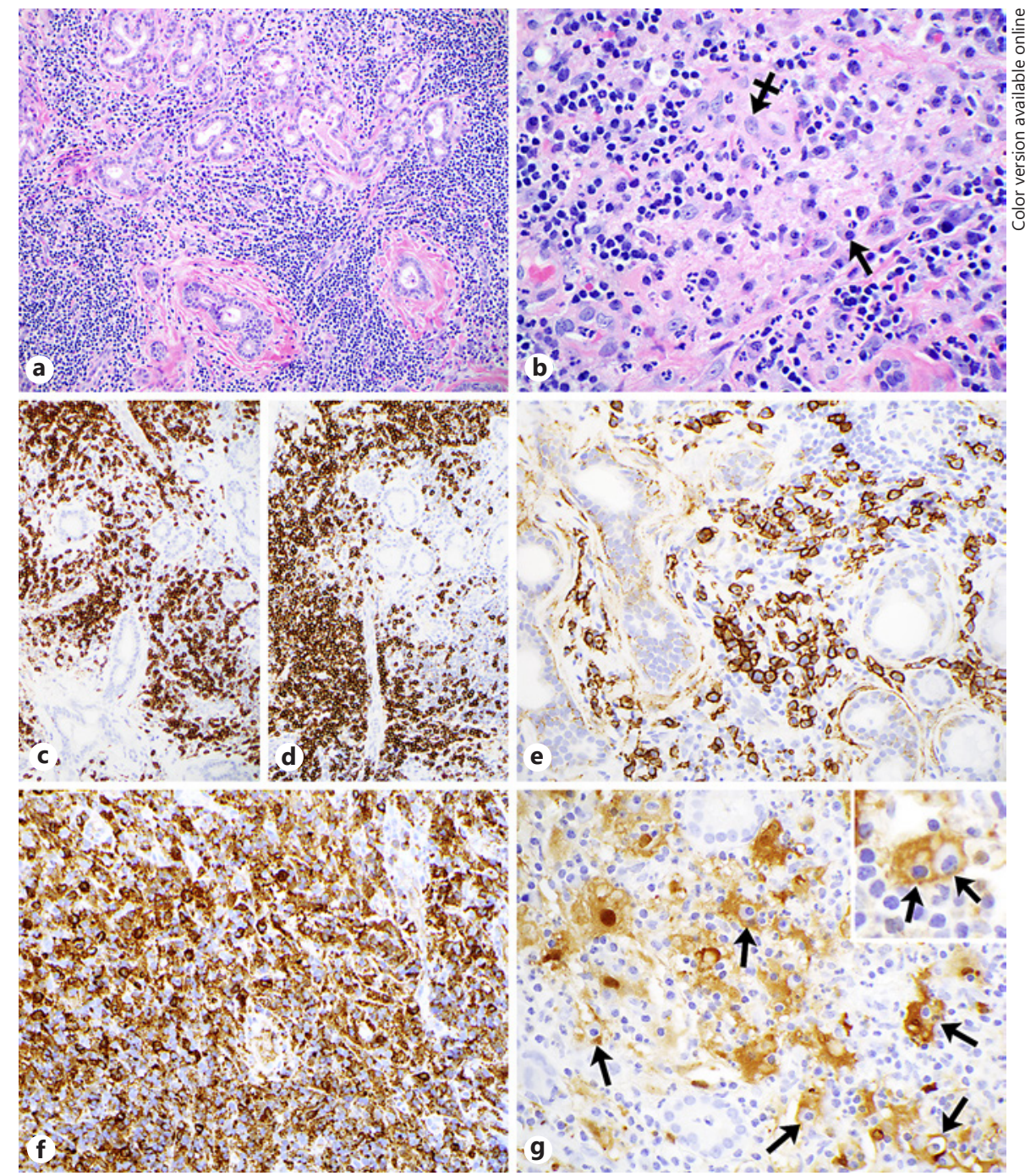

(LCH), Hodgkin's lymphoma, or T-cell lymphoma $[2,5]$. In extranodal RDD, increased fibrosis and fewer histiocytes are present in the lesions. Typically, the histiocytes demonstrate an abundant foamy or vacuolated eosinophilic cytoplasm with large, round, hypochromatic nuclei $[2,5]$.

Immunohistochemical stains are helpful in establishing the diagnosis. RDD histiocytes stain positively for CD68 (KP-1), CD163, and S100 and are typically negative for CD1a [5]. A negative stain with CD1a and absence of ultrastructural rod-shaped Birbeck granules help to distinguish RDD from LCH [15].

Orbital involvement is very rare and can be an isolated extranodal manifestation or associated with concurrent systemic disease. In the largest case series of RDD published in 1979,13 out of 113 cases (11\%) had periocular infiltration [2], with 11 of the 13 cases involving the orbital soft tissues. Involvement of orbital soft tissues and the eyelids is the most common reported ophthalmic manifestation. Involvement of the lacrimal gland (unilateral $[9,16]$ or bilateral [17]), conjunctiva [7], uvea [18], cornea [8], and retina [18] has been described. Orbital disease is generally associated with a higher risk of involvement of other extranodal sites, especially the sinonasal mucosa [2].

Bony involvement is exceedingly rare in RDD, and symptoms typically include pain and swelling $[6,19]$. There are $188 \mathrm{RDD}$ patients with bone involvement reported in the literature [19], and 35\% (67/188) had primary RDD of the bone. The cranial and facial bones as well as long bones are the most frequently affected sites. Imaging usually demonstrates lytic lesions (53/67) and 
Table 1. Summary of literature review of patients with Rosai Dorfman disease involving the lacrimal gland

\begin{tabular}{|c|c|c|c|c|c|c|c|c|}
\hline & $\begin{array}{l}\text { First author } \\
\text { [ref.], year }\end{array}$ & $\begin{array}{l}\text { Age, } \\
\text { years/sex }\end{array}$ & Presenting symptoms & $\begin{array}{l}\text { Systemic } \\
\text { involvement }\end{array}$ & $\begin{array}{l}\text { Bony } \\
\text { involvement }\end{array}$ & Laterality & Immunohistochemistry & $\begin{array}{l}\text { Treatment/outcome } \\
\text { (when mentioned) }\end{array}$ \\
\hline 1 & $\begin{array}{l}\text { Tan }[10], \\
2016 \\
\text { (case series) }\end{array}$ & $10 / \mathrm{M}$ & $\begin{array}{l}\text { Superior periorbital } \\
\text { masses }\end{array}$ & None & None & Bilateral & Not discussed & Complete excision/resolution \\
\hline 2 & $3 / 8$ patients & $10 / \mathrm{M}$ & $\begin{array}{l}\text { Superior periorbital } \\
\text { masses, diplopia, } \\
\text { decrease EOM }\end{array}$ & Lymph nodes & None & Bilateral & Not discussed & $\begin{array}{l}\text { Debulking/improved residual } \\
\text { disease }\end{array}$ \\
\hline 3 & & $78 / \mathrm{F}$ & $\begin{array}{l}\text { Superior periorbital } \\
\text { masses, ptosis, pain }\end{array}$ & Lymph nodes, parotid gland & None & Bilateral & Not discussed & $\begin{array}{l}\text { Debulking/improved residual } \\
\text { disease }\end{array}$ \\
\hline 4 & $\begin{array}{l}\text { Hsu }[20] \\
2013 \\
\text { (case report) }\end{array}$ & $69 / \mathrm{F}$ & Painless palpable mass & Hilar lymphadenopathy & None & Unilateral & $\begin{array}{l}\text { (+) S-100 protein, } \\
\text { (+) emperipolesis }\end{array}$ & Complete excision/resolution \\
\hline 5 & $\begin{array}{l}\operatorname{Li}[21] \\
2012 \\
\text { (case report) }\end{array}$ & $72 / \mathrm{M}$ & Painless palpable mass & None & None & Unilateral & $\begin{array}{l}\text { (+) CD 68, (+) S-100, } \\
\text { (+) CD20, (+) CD21, } \\
\text { (+) CD35, (+) CD } 34, \\
\text { (-) CD1a, (-) CD } 30, \\
\text { (-) CK, (-) P53, } \\
\text { (+) emperipolesis }\end{array}$ & Complete excision/resolution \\
\hline 6 & $\begin{array}{l}\text { Raslan }[22] \\
2011 \\
\text { (case series) }\end{array}$ & $4 / \mathrm{F}$ & Proptosis & $\begin{array}{l}\text { Neck lymph nodes and } \\
\text { parotid gland }\end{array}$ & None & Bilateral & $\begin{array}{l}\text { Pathology proven } \\
\text { (details not included) }\end{array}$ & $\begin{array}{l}\text { Chemotherapy and oral } \\
\text { corticosteroid }\end{array}$ \\
\hline 7 & $\begin{array}{l}\text { Kruse [23], } \\
2010 \\
\text { (case report) }\end{array}$ & $27 / \mathrm{M}$ & $\begin{array}{l}\text { Proptosis and swelling } \\
\text { with displacement } \\
\text { of globe }\end{array}$ & $\begin{array}{l}\text { None on initial presentation, } \\
\text { hilar lymph node involvement } \\
4 \text { years later }\end{array}$ & None & $\begin{array}{l}\text { Unilateral on } \\
\text { presentation } \\
\text { with bilateral } \\
\text { involvement } \\
4 \text { years after }\end{array}$ & $\begin{array}{l}\text { (+) S-100, } \\
(+) \text { emperipolesis }\end{array}$ & $\begin{array}{l}\text { Complete excision/recurrence } \\
\text { followed by steroid/resolution }\end{array}$ \\
\hline 8 & $\begin{array}{l}\text { Yuen }[9] \text {, } \\
2006 \\
\text { (case report) }\end{array}$ & $29 / \mathrm{M}$ & $\begin{array}{l}\text { Painful mass in upper } \\
\text { eyelid }\end{array}$ & $\begin{array}{l}\text { None on presentation, } \\
\text { osteolytic lesion of the } \\
\text { humerus bone }\end{array}$ & Yes & Unilateral & $\begin{array}{l}\text { (+) S-100, (+) CD } 68 \\
\text { (+) emperipolesis, } \\
\text { (-) CD1a }\end{array}$ & $\begin{array}{l}\text { Debulking/improved residual } \\
\text { disease }\end{array}$ \\
\hline 9 & $\begin{array}{l}\text { Lee-Wing } \\
{[17], 2001} \\
\text { (case report) }\end{array}$ & $14 / \mathrm{M}$ & $\begin{array}{l}\text { Painless orbital } \\
\text { swelling }\end{array}$ & $\begin{array}{l}\text { Massive bilateral swelling of } \\
\text { salivary gland and cervical } \\
\text { lymphadenopathy and } \\
\text { fever - developed } 9 \text { month } \\
\text { following initial presentation }\end{array}$ & None & Bilateral & $(+)$ emperipolesis & Complete excision \\
\hline 10 & $\begin{array}{l}\text { Gulwani } \\
{[24], 2008} \\
\text { (case report) }\end{array}$ & $38 / \mathrm{M}$ & $\begin{array}{l}\text { Painless swelling of } \\
\text { the upper eyelid with } \\
\text { mild proptosis and } \\
\text { dystopia }\end{array}$ & None & None & Unilateral & $\begin{array}{l}(+) \text { S-100, (+) CD68, } \\
(+) \text { emperipolesis }\end{array}$ & Complete excision/resolution \\
\hline 11 & $\begin{array}{l}\text { Kaur [27], } \\
2005 \\
\text { (case report) }\end{array}$ & $37 / \mathrm{M}$ & $\begin{array}{l}\text { Tender mass over } \\
\text { eyelid, patient with } \\
\text { SLE }\end{array}$ & $\begin{array}{l}\text { Soft tissue nodule within } \\
\text { retroperitoneum, } \\
\text { lymphadenopathy }\end{array}$ & None & Bilateral & $\begin{array}{l}(+) \text { S-100, (-) CDla, } \\
\text { (+) emperipolesis }\end{array}$ & Spontaneous resolution \\
\hline 12 & $\begin{array}{l}\text { Azoulay [25], } \\
2004 \\
\text { (case report) }\end{array}$ & $7 / \mathrm{M}$ & Left orbital mass & $\begin{array}{l}\text { Recurrent cervical } \\
\text { lymphadenopathy followed } \\
\text { by supraorbital mass }\end{array}$ & None & Unilateral & $\begin{array}{l}(+) \mathrm{CD} 68,(+) \mathrm{CD} 3 \\
(+) \mathrm{CD} 20,(-) \mathrm{CD} 1 \mathrm{a}\end{array}$ & $\begin{array}{l}\text { Oral corticosteroid/decrease in size } \\
\text { of mass }\end{array}$ \\
\hline 13 & $\begin{array}{l}\text { Quintyn } \\
{[26], 2002}\end{array}$ & $7 / \mathrm{M}$ & Proptosis & None & None & Unilateral & $\begin{array}{l}\text { (+) S-100, (+) CD68, } \\
(-) \text { CD1a, (+) emperipolesis }\end{array}$ & Complete excision/resolution \\
\hline 14 & $\begin{array}{l}\text { (case series) } \\
2 \text { patients }\end{array}$ & $57 / \mathrm{M}$ & $\begin{array}{l}\text { Swelling of upper } \\
\text { eyelid }\end{array}$ & None & None & Unilateral & & Debulking \\
\hline 15 & $\begin{array}{l}\text { Reddy [16], } \\
2001 \\
\text { (case report) }\end{array}$ & $36 / \mathrm{M}$ & $\begin{array}{l}\text { Redness and severe } \\
\text { proptosis, choroidal } \\
\text { folds }\end{array}$ & $\begin{array}{l}\text { Cervical lymphadenopathy, } \\
\text { nasal and sinus mucosa } \\
\text { thickening and bleeding }\end{array}$ & None & Unilateral & Not discussed & Oral corticosteroid/resolution \\
\hline 16 & $\begin{array}{l}\text { Beckingsale } \\
{[28], 2002} \\
\text { (case report) }\end{array}$ & $78 / \mathrm{F}$ & Eyelid swelling & $\begin{array}{l}\text { Cervical and submandibular } \\
\text { lymphadenopathy }\end{array}$ & None & Unilateral & $\begin{array}{l}\text { (+) CD 68, (+) S-100, } \\
(-) \text { CD 1a, (-) CD 30, } \\
\text { (-) CD15, } \\
\text { (+) emperipolesis }\end{array}$ & Complete excision/resolution \\
\hline 17 & Our case & $32 / \mathrm{M}$ & $\begin{array}{l}\text { Eyelid swelling, } \\
\text { proptosis, secondary } \\
\text { optic neuropathy }\end{array}$ & None & Yes & Unilateral & $\begin{array}{l}\text { (+) CD 68, (+) CD 163, } \\
\text { (+) S-100, (+) CD3, } \\
\text { (+) CD 138 (+) CD20, } \\
(-) \text { CD 1a, } \\
\text { (+) emperipolesis }\end{array}$ & $\begin{array}{l}\text { Debulking followed by oral } \\
\text { corticosteroid/resolution of ocular } \\
\text { symptoms and reversal of } \\
\text { secondary optic neuropathy }\end{array}$ \\
\hline
\end{tabular}

EOM, extraocular motility; SLE, systemic lupus erythematosus 
less commonly partially lytic and partially sclerotic lesions (12/67) [19].

We conducted a literature search of all cases of RDD involving the lacrimal gland (data summarized in Table 1). Including our patient, there were only 17 cases of RDD involving the lacrimal gland reported in the literature (Table $1[9,10,16,17,20-28])$. The median age of these patients was 32 years (range 4-78). Thirteen out of 17 (76\%) cases were male. The most common presentation was a painless orbital mass, followed by swelling of the eyelids and proptosis. Secondary optic neuropathy, as seen in our patient, has not been reported. Six out of the 17 patients (35\%) displayed isolated lacrimal gland disease with no systemic involvement. The most common type of systemic involvement was cervical lymphadenopathy. Seven out of 17 patients demonstrated bilateral lacrimal gland involvement (41\%), with 1 of these cases progressing from unilateral to bilateral disease. Bony involvement in RDD is extremely rare; there was only 1 other case in the literature of lacrimal gland involvement with adjacent bony lytic lesions. Our case is the first to demonstrate bony involvement that is not merely erosive but appears to excavate the orbital wall with a punchedout appearance.

The differential diagnosis of RDD is broad and depends on the site of anatomical involvement; it includes malignant and nonmalignant etiologies. Nonmalignant etiologies include tuberculosis, sarcoidosis, granulomatosis with polyangiitis, juvenile xanthogranuloma, LCH, Löffler's syndrome, and IgG4-related disease. Malignant etiologies include Hodgkin's lymphoma, non-Hodgkin's lymphoma, melanoma, leukemia, and Langerhans cell sarcoma. RDD of the orbit can mimic orbital pseudotumor, tuberculous granuloma, LCH, juvenile xanthogranuloma, rhabdomyosarcoma, Erdheim-Chester disease, meningioma, lymphoma, malignant histiocytosis, and reactive sinus hyperplasia. If the lacrimal gland is involved, dacryoadenitis and epithelial gland tumors must also be considered. Finally, when bony lesions are associated with lacrimal gland enlargement, as seen in our case, it is critical to rule out lacrimal gland adenocarcinoma, adenoid cystic carcinoma, granulocytic sarcoma (chloroma), benign (reactive) and malignant osteogenic tumors, and metastatic neuroblastoma in children.

$\mathrm{RDD}$ is a nonmalignant histiocytic disorder with an indolent and self-limited course in the majority of patients $[3,5,14]$. Patients diagnosed with RDD should undergo a thorough systemic evaluation. Treatment is usually not necessary in clinically stable patients as they often experience spontaneous resolution [29]. Complete surgi-

Atypical Rosai-Dorfman Disease of the Lacrimal Gland cal excision or debulking constitutes a first-line option for patients with nodal or extranodal disease affecting organ function, quality of life, or involving the central nervous system $[3,5,14]$. Systemic corticosteroids, chemotherapy, and radiation therapy can result in reduction of disease burden and durable remission in some cases $[3,5$, 14]. On the other hand, a higher percentage of patients with orbital RDD required treatment as orbital involvement resulted in significant morbidity and visual compromise [30].

Based upon our literature review of RDD with lacrimal gland involvement (Table 1), surgical intervention with complete excision or debulking was the treatment of choice in 13 out of the 17 cases (76\%) and resulted in complete resolution or improved residual disease. One case in addition to ours required additional oral corticosteroids to control residual disease. In 3 out of the 17 cases (17\%) where surgical intervention was not possible, oral corticosteroids were sufficient to attain near complete resolution of symptoms. In 1 case, the signs and symptoms of RDD resolved in the absence of treatment.

The prognosis of RDD is usually favorable [6]. In 1 study, the mortality rate was estimated as high as 7\%; however, only 2 cases were directly caused by the disease itself, and the rest could be attributed to complications of other defined immunologic abnormalities or infectious causes [31]. Coexistence of RDD with lymphoma $[6,14]$ and generalized AA amyloidosis [32] has been described; thus, routine surveillance is important to monitor for potential malignant transformation, systemic manifestation, and visual compromise.

\section{Conclusion}

Although rare, RDD should be considered in the differential diagnosis of an orbital mass involving the lacrimal gland with associated bone erosion, along with malignant lesions of the lacrimal gland. A referral to a medical oncologist or hematologist is recommended for evaluation and management of systemic involvement. Localized disease of the lacrimal gland is otherwise treated successfully with excision and/or systemic corticosteroids based upon our experience and a review of the cohort of subjects in the literature.

\section{Statement of Ethics}

Written informed consent was obtained from the patient for this report. 


\section{Disclosure Statement}

The authors have no financial disclosures or conflicts of interest to report.

\section{Funding Sources}

Heed Fellowship to N.W.

\section{References}

1 Rosai J, Dorfman RF: Sinus histiocytosis with massive lymphadenopathy. A newly recognized benign clinicopathological entity. Arch Pathol 1969;87:63-70.

2 Foucar E, Rosai J, Dorfman RF: The ophthalmologic manifestations of sinus histiocytosis with massive lymphadenopathy. Am J Ophthalmol 1979;87:354-367.

3 Dalia S, Sagatys E, Sokol L, Kubal T: RosaiDorfman disease: tumor biology, clinical features, pathology, and treatment. Cancer Control 2014;21:322-327.

4 Rosai J, Dorfman RF: Sinus histiocytosis with massive lymphadenopathy: a pseudolymphomatous benign disorder. Analysis of 34 cases. Cancer 1972;30:1174-1188.

5 McClain KL, Natkunam Y, Swerdlow SH: Atypical cellular disorders. Hematology Am Soc Hematol Educ Program 2004:283-296.

6 Foucar E, Rosai J, Dorfman R: Sinus histiocytosis with massive lymphadenopathy (RosaiDorfman disease): review of the entity. Semin Diagn Pathol 1990;7:19-73.

7 Fernandez FJ, Melcon B, Alvarez R, Honrubia FM: Subconjunctival mass in Rosai-Dorfman disease. Eur J Ophthalmol 1998;8:263-264.

8 Rumelt S, Cohen I, Rehany U: Marginal corneal infiltrates: a possible new manifestation of sinus histiocytosis with massive lymphadenopathy. Cornea 2000;19:857-858.

9 Yuen HK, Cheuk W, Leung DY, Tse RK, Chan N: Atypical presentation of Rosai-Dorfman disease in the lacrimal gland mimicking malignancy. Ophthalmic Plast Reconstr Surg 2006;22:145-147.

10 Tan JJ, Narang S, Purewal B, Langer PD, Blaydon S, Schwarcz RM, McCormick SA, Kim JY, Walrath JD, Burt BO, Shinder R: Extranodal Rosai-Dorfman disease of the orbit: clinical features of 8 cases. Ophthalmic Plast Reconstr Surg 2016;32:458-461.

11 Mehraein Y, Wagner M, Remberger K, Fuzesi L, Middel P, Kaptur S, Schmitt K, Meese E: Parvovirus B19 detected in Rosai-Dorfman disease in nodal and extranodal manifestations. J Clin Pathol 2006;59:1320-1326.

12 Tanaka T, Asano S, Takahashi K, Miyoshi I, Tanaka M, Hayashi T, Saito R, Muguruma M: Sinus histiocytosis with massive lymphadenopathy in a Japanese adult with unusually elevated EBV antibody titers. Acta Pathol Jpn 1980;30:121-135.
13 Morgan NV, Morris MR, Cangul H, Gleeson D, Straatman-Iwanowska A, Davies N, Keenan S, Pasha S, Rahman F, Gentle D, Vreeswijk MP, Devilee P, Knowles MA, Ceylaner S, Trembath RC, Dalence C, Kismet E, Koseoglu V, Rossbach HC, Gissen P, Tannahill D, Maher ER: Mutations in SLC29A3, encoding an equilibrative nucleoside transporter ENT3, cause a familial histiocytosis syndrome (Faisalabad histiocytosis) and familial Rosai-Dorfman disease. PLoS Genet 2010;6:e1000833.

14 McClellan SF, Ainbinder DJ: Orbital RosaiDorfman disease: a literature review. Orbit 2013;32:341-346.

15 O’Malley DP, Duong A, Barry TS, Chen S, Hibbard MK, Ferry JA, Hasserjian RP, Thompson MA, Richardson MS, Jaffe R, Sidhu JS, Banks PM: Co-occurrence of Langerhans cell histiocytosis and Rosai-Dorfman disease: possible relationship of two histiocytic disorders in rare cases. Mod Pathol 2010;23: 1616-1623.

16 Reddy A, Beigi B, Linardos E: Rosai-Dorfman syndrome affecting the lacrimal gland. Orbit 2001;20:239-242.

17 Lee-Wing M, Oryschak A, Attariwala G, Ashenhurst M: Rosai-Dorfman disease presenting as bilateral lacrimal gland enlargement. Am J Ophthalmol 2001;131:677-678.

18 Vermeulen TL, Isaacs TW, Spagnolo D, Amanuel B: Rosai-Dorfman disease presenting as choroidal melanoma: a case report and review of the literature. Graefes Arch Clin Exp Ophthalmol 2013;251:295-299.

19 Mosheimer BA, Oppl B, Zandieh S, Fillitz M, Keil F, Klaushofer K, Weiss G, Zwerina J: Bone involvement in Rosai-Dorfman Disease (RDD): a case report and systematic literature review. Curr Rheumatol Rep 2017;19:29.

20 Hsu HY, Chen ZT, Tsai CY, Liou SW, Woung LC: Atypical Rosai-Dorfman disease with lacrimal gland involvement. Semin Ophthalmol 2013;28:253-255.

21 Li J, Ge X, Ma JM, Li M: Rosai-Dorfman disease of unilateral lacrimal gland in an elderly Chinese male. Int J Ophthalmol 2012;5:541542.
22 Raslan OA, Schellingerhout D, Fuller GN, Ketonen LM: Rosai-Dorfman disease in neuroradiology: imaging findings in a series of 10 patients. AJR Am J Roentgenol 2011;196: W187-W193.

23 Kruse AL, Gengler C, Gratz KW, Obwegeser JA: Extranodal manifestation of Rosai-Dorfman disease without involvement of lymph nodes. J Craniofac Surg 2010;21:1733-1736.

24 Gulwani H, Bhalla S, Srivastava A: Isolated lacrimal gland involvement in Rosai-Dorfman-Destombes disease. Indian J Ophthalmol 2008;56:507-509.

25 Azoulay R, Brisse H, Freneaux P, Ferey S, Kalifa G, Adamsbaum C: Lacrimal location of sinus histiocytosis (Rosai-Dorfman-Destombes disease). AJNR Am J Neuroradiol 2004; 25:498-500.

26 Quintyn JC, Ranty ML, Courville P, Metayer J, Retout A: Orbital sinus histiocytosis (RosaiDorfman disease): a lacrimal gland involvement. Ophthalmologica 2002;216:277-280.

27 Kaur PP, Birbe RC, DeHoratius RJ: RosaiDorfman disease in a patient with systemic lupus erythematosus. J Rheumatol 2005;32: 951-953.

28 Beckingsale P, Sullivan T, Whitehead K: A case of Rosai-Dorfman disease involving the lacrimal gland in an elderly patient. Orbit 2002;21:169-175.

29 Pulsoni A, Anghel G, Falcucci P, Matera R, Pescarmona E, Ribersani M, Villiva N, Mandelli F: Treatment of sinus histiocytosis with massive lymphadenopathy (Rosai-Dorfman disease): report of a case and literature review. Am J Hematol 2002;69:67-71.

30 Mohadjer Y, Holds JB, Rootman J, Wilson MW, Gigantelli JW, Custer PL: The spectrum of orbital Rosai-Dorfman disease. Ophthalmic Plast Reconstr Surg 2006;22:163-168.

31 Foucar E, Rosai J, Dorfman RF: Sinus histiocytosis with massive lymphadenopathy. An analysis of 14 deaths occurring in a patient registry. Cancer 1984;54:1834-1840.

32 Rocken C, Wieker K, Grote HJ, Muller G, Franke A, Roessner A: Rosai-Dorfman disease and generalized AA amyloidosis: a case report. Hum Pathol 2000;31:621-624. 